\title{
Major Climate Change Adaptation and Coping Strategies in Borana, Southern Ethiopia: A Review
}

\author{
Fikru Tilahun $^{1^{*}} \quad$ Brook Legese $^{2^{*}}$ \\ 1.Lecturer and Researcher at Bule Hora University, Department of Natural Resources Management,Bule Hora, \\ Ethiopia
}

2.Lecturer and Researcher at Bule Hora University, Head, Department of Natural Resources Management,Bule Hora, Ethiopia

\begin{abstract}
Climate change is one of the global problems in todays world. This problem is in agrivating level that caused by both natural and antropogenic drivers. This problem has efffects on environmental,social,economic and political sustainability. However, often human being have been tried to create adptation and coping mechanism so that minimize negative effects of climate change and to take advantage of it. This paper is aimed to identify and disscuss major climate change adaptation and coping strategies in Borana pastoral area. Borena pastoral people are one of those people that majorly known by livestok raring. As most of pastoralist these people faced the challenges of the climatic change particularly through prolonged drought. But, they have being trying to tackle these problems through different adaptation and coping measures. Moreover,these adaptation and coping measures are classifeid into four broad section in this papper to address the entended objective. These are livestock, range, incomediversification and water-related measures.But these adaptation and coping measurs face different challenges such as, infrustructural limmitation, limitation related to service and facilitiy,reptability of climatic change event, and lack of well documentation on these measures that script on the book. Therefore, all stackholders should works to play their part to sustain such invaluable strategies.
\end{abstract}

Keywords: Climate Change, Adaptation, Coping measure, Livestock,Borena Pastoralist

DOI: $10.7176 / \mathrm{JRDM} / 69-01$

Publication date:October $31^{\text {st }} 2020$

\section{INTRODUCTION}

Globally, climate change is one of the most important environmental issues and challenges of the twenty-first century (UNFCCC, 2007). The extent of climate change effects on individual regions vary over time and wIth the ability of different societal and environmental systems to mitigate or adapt to change. The East African region is considered in several climate analyses that it will be drier, with reduction in the length of the growing season. Maping of vulnerability to climate change of Africa has put Ethiopia as one of the most vulnerable and with the least capacity to respond (Thornton et al., 2006). In Ethiopia, climate variability and change have resulted in frequent droughts, floods, heavy rains, strong winds, and heat waves (Abebe, 2007). The reason why Ethiopia is vulnerable to climate change is, because of its greater reliance on climate sensitive economic sector like subsistence crop cultivation and livestock production (Sector, 2014).

Ethiopia has a diversified climate, which has different size and diversity of major agro-ecological zones render it suitable for the support of large numbers and classes of livestock. More than 10 million people of Ethiopia are pastoralists (CSA, 2008), herding their livestock in the arid and semi-arid lowlands that constitute about $61 \%$ of the country's land mass (MARD, 2008). These areas are prone to rainfall variability, extreme drought and flash floods. In pastoral areas of Ethiopia, climate change increased the burden of those who are already poor and vulnerable by affecting their livelihood pattern and strategies and triggering food, feed, water and social insecurity (Sector, 2014). Over the last decade, drought has recurred in southern Ethiopia more frequently and for longer periods than documented previously. The region's changing climate has resulted in diminished quantity and quality of local water and forage resources, thereby severely and negatively impacting the region's livestock and the nomadic pastoralists, such as the Boran, who depend on these animals for livelihoods and subsistence(Hurst et al. 2012).

Traditionally, the Boran have been almost totally dependent for their livelihoods on the products of their cattle, using them as food or in trade for grain. In turn, the cattle depend on the stewardship of the Boran people, as well as the regeneration of grazing lands through frequent and intense seasonal rains (Hurst et al. 2012). Currently, the Borana pastoral system has suffered greater cattle die offs due to recurrent droughts. Grazing resources are deteriorating with increasing bush encroachment and declining in forage production. The effects of droughts and bush encroachment are major drivers of forage scarcity, causing cattle mortality in southern Ethiopia (Wako et al. 2017). However, pastoralists are struggling to overcome the risks of climatic change by using and improving different adptation and coping strategies. Therefore, this tried to is aimed to identfy and disscuss climate change adaptation and coping strategies in case of Borana pastoralist. 


\section{Major climate change adaptation and coping strategies of Borana pastoralist.}

Coping strategies refers to the strategies that have evolved over time through peoples' long experience in dealing with the known and understood natural variation that they expect in seasons combined with their specific responses to the season as it unfolds (Cooper et al., 2008). Pastoral communities have developed various traditional adaptation mechanisms over the years to minimize their vulnerabilities to the impacts of climate variability (Omolo 2010; Tache 2010). In order to simplify the discussion the major coping strategies employed by Borana pastoralists was grouped in to four major groups and discussed as follow:

\section{A. Livestock-related Adaptation and Coping Strategies}

Livestock production is the main livelihood basis of the Borana pastoralists (Tolera and Abebe, 2007). The livestock-related coping strategies include reducing livestock size, livestock mobility, livestock diversification, traditional social insurance, and maintaining animal health.

\section{i. Herd Mobility}

Mobility is a survival and resource management strategy commonly practiced by herder societies for efficient use of meagre and scattered rangeland resources for sustainable livelihoods in the face of climate fluctuations in dryland ecosystems. It is a good practical instance of locally adapted livelihood strategies in dryland areas (Martin et al. 2014)

As nomadic pastoralists, the Boran travel with their livestock in search of water and pasture. Movement is dictated by season and the availability of forage, as well as personal relationships, family structure, and immediate demands rains (Hurst et al. 2012). These report also supported by (Dirriba, 2016), Herd mobility is one of the long history livestock related coping strategies that dictated by season and the availability of forage, as well as personal relationships, family structure, and immediate demands in search of water and pasture.

Migration is realized as coping strategies in step-by-step manner that depends on the severity condition of drought. Based on the status of forage and water condition, the first action is separating and letting the lactating cow and calves around home stead and then the herder (household head or a group of young herder) migrate with other livestock. However, they return to their homestead otherwise they migrated with all family and livestock if the condition become worsen (Dirriba, 2016).

In addition, herd mobility is aided by a network of watering points and wells maintained throughout Borana. Operation and maintenance of these points is controlled through the gada system. Prior to the emergence of recent climate-related changes, migration was limited to mainly wet and dry grazing areas, meaning that different pastures were used during the wet and dry seasons, and that traditional laws governed the use of these resources. As climate change has accelerated, the Borana has altered how they migrate, when, where, and for how long. The Boran now travel significantly greater distances to reach pasture and water, which takes more time and requires men to be away from home for longer periods(Hurst et al. 2012).

ii. Livestock Diversification

Diversification into different species of livestock allows the household to maintain animals that feed on different species of plants, increasing their options for extracting resources from the rangeland (Hurst et al. 2012). As reported by the same authors Livestock diversification has become one of the most universally adopted coping mechanisms in Borana. Nearly all Boran have multispecies herds that include goats, with increasing numbers of herds adding camels.

Traditionally, the Borana pastoral system of southern Ethiopia is based on cattle husbandry for survival and income generation. This traditional system of cattle production had been effective over generations in producing animal products with a robust management and maintenance of rangeland resources (Oba 1998). A person without a head of cattle in the Borana custom is considered as qolle (destitute) and "incomplete" because of the comprehensive social functions bestowed upon cattle in the indigenous constitution (Wassie and fekadu, 2015).In recent years, due to the impact of climate change, the Borana pastoralists have started to gradually diversify livestock and vary the composition of their herds to match the local environmental conditions (Megersa et al. 2014; Oba 2014)

Herd diversification in favor of browsers (camel and goats) is another important strategy of pastoralist adaptive response to climate-induced shifts in rangeland ecosystems. As reported by (Wassie and fekadu, 2015)camel has never gained as such status of traditional completeness in its functions, in that it has in no way been valuably recognized for use in social and religious rituals, local wealth redistributions, dowry and ceremonial gifts, and payment of fines. Therefore, Borana herders, especially in the past, always remained hesitant to uphold camel in their traditional herd management decisions perhaps except for as a beast of burden (Wassie and fekadu, 2015). As reported by (Hurst et al. 2012) as the landscape in southern Ethiopia has become drier, the presence of drought-tolerant livestock has increased. Currently, proportions of different types of cattle in Boran herds are being reduced relative to goats and camels, which are more drought tolerant and disease resistant.

iii. Destocking

Destocking is an emergent act of reducing the herd size from their flock mostly as a coping mechanism during severe drought (Hurst et al., 2012). The main target of destocking is to reduce livestock death, to moderate the 
feed competition during severe drought and to covert livestock in kind to a liquid form (Dirriba, 2016).

The Boran appear to be reducing their herd size as a coping mechanism for several reasons. First, it minimizes risk and allows the Boran greater financial gain than would be possible if the animal were to die. Secondly, income from the sale of livestock can be used to buy household goods or other urgent needs. While this offers immediate relief, it is problematic with respect to the market. The Boran are selling their livestock when the market is flooded and prices are low(Hurst et al., 2012).

\section{iv. Maintaining Animal Health}

Animal health is one of the Boran system's greatest strengths. Local knowledge of cattle husbandry and health is substantial, and appears to be very accurate and well applied. The government vaccination program is well organized and executed, especially in light of resource constraints in the region (Hurst et al., 2012).

\section{v. Improvement Livestock Management}

In borena pastoralist people another livestock related adaptation and coping mechanism that majorly focus on modern methods is improvement livestock management. These measure are applied through the improvement of cattle breeding center and castration of bulls. Boran Cattle Breeding Center is the center that dedicated to the preservation and improvement of Boran cattle breed, and raises several hundred cattleon government land. The center has excellent knowledge of husbandry, as well as of regional impediments to cattle health. Furthermore, the center identifies outstanding farmers annually in different woredas and sells breeding stock to those farmers in order to perpetuate the breed and to introduce genetic diversity. The center could be utilized for extension and training in order to preserve the Boran breed, and to facilitate farmers in maintaining optimal cattle health in order to enable cattle to survive periods of drought (Hurst et al., 2012).

Another improvement of livestock management carried out through castlation. The Steers (castrated bulls) tend to have more desirable composition of external fat and marbling, but this is offset by their tendency toward decreased rate of weight gain and a lower feed conversion efficiency (Schanbacher, 1984 and Seidemen et al., 1982). As reporeted by Hurst et al., (2012); Boran that castration of bulls increases their drought resistance and reduces their calorie requirements.

vi.

\section{Traditional Social Insurance}

Social assistant is a deep-rooted ethos along with history of Borana society (Dirriba, 2016). In the event of massive die-offs of cattle, the Boran rely on a traditional three-tiered insurance system. The first tier is busa gonafa, a community-based re-stocking program in which several Boran families, whose cattle have survived, give a cow to a Boran family that has lost their entire herd. The cow is a permanent gift and is intended to help the family begin to rebuild their herd. The second is ames, a short-term loan extended from one Boran family to another in the form of a lactating cow. The Boran family that receives the lactating cow may keep the cow and use her milk for one lactation cycle (typically less than six months in Borana) and then must return the cow. The third tier is rebaray, a charitable donation in which a single Boran family gives a cow to another Boran family following the complete loss of their herd. The cow is a gift, and the family that receives the cow has full rights to the cow, her milk, and her offspring. In order for this system to work and be perpetuated, the families that are donating and lending cattle must have a minimum of five cows. Families that do not meet this minimum requirement are not asked to make donations (Hurst et al., 2012).

\section{B. Rangeland-Related Adaptation and Coping strategies}

The primary means by which pastoralists, like communities everywhere, will feel the impacts of climate change is in changes in land and water resources. The Boran have been living with scarce pastureland and water for generations. A number of rangeland-related risk-mitigation measures have been undertaken by Boran communities, as well as initiated by the government and NGOs. Many of these measures have been in use for at least decades, and were developed in response to local climatic fluctuations (Hurst et al., 2012).

\section{i. $\quad$ Land classification based on grazing season}

The Boran have sophisticated traditional systems of managing land and water resources. Regions are designated as wet season grazing areas and dry season grazing areas. The dry season grazing areas tend to be areas of relatively lower elevation where water accumulates, there y allowing pasture growth even in the absence of significant rainfall. This system may be especially useful if droughts become more frequent and/or severe since it allows Boran communities to together reserve a part of pasture for drier times of the year. While this system alone is not adequate, having some pasture reserved for the dry season might allow the communities some additional time to plan responses in a bad year (Hurst et al., 2012).

\section{ii. Kallo enclosure reserve}

Kallos are enclosures which are reserved for lactating, sick or young animals, so that these animals do not have to travel the much larger distances traveled by the rest of the herd for pasture particularly in the dry season. These report also supported by (Wassie and fekadu, 2015); as kaloo is well-known adopted practice in the area to keep village communal fodder banks (kallo) that used to feed calves, weak animals, and milking cows during feeddeficit dry months.

Neither "imported" hay purchases nor large local production and stockpiling of hay were known in the past 
traditional pastoral practice of Borana pastoralism Though the traditional enclosures for calves were smaller and called seera yabbiye, or "calf reserve" (Helland, 1994), kallos, which are an "imported" strategy have become very common. The kallos, which may be for the use of the whole village or a group of households, are built by clearing a patch of land of bushes, and are often fenced by dried bush. Kallos range in size from one to tens of hectares (Solomon et al., 2007), and account for almost a tenth of the total land area surrounding ommunities (McCarthy et al., 2003). Communities often build kallos under government and NGO initiatives. In times of drought, kallos may mitigate to an extent the distances that weaker animals have to travel for pasture, and like wet/dry grazing areas may provide at least temporary relief.

\section{iii. $\quad$ Bush Clearing}

The availability and quality of valuable forage species are declining in the rangelands of southern Ethiopia as a result of bush encroachment (Angassa and Baars, 2000). Similarly, Dirriba (2016) has documented as Bush is bottle neck to rangeland where unimportant trees are intensively invaded the rangeland. Moreover bush encroachment will likely interfere with the ability of the Boran to adapt to increased climatic pressures as it effectively reduces the pastureland available. Moreover, areas which have been encroached by bush have little grass seed left in the soil, making reestablishment of grass very difficult (Hurst et al., 2012).

Bush clearing and/or thinning with efficient rangeland restoration techniques will recovers the shortage of feed resources. Furthermore, improving livestock feeding system need an equivalent attention to improve the sustainable uses of water and forage development (Dirriba, 2016).

\section{iv. $\quad$ Forest Management}

Trees are used as alternative sources of fodder for browsing livestock (camels, goats and sheep) in times of drought. Trees also reduce land degradation and maintain a better microclimate for livestock (shade and moisture (Siri and Andrei, 2011). The linkages between forests and adaptation are two-fold (Bekele, 2017). First, adaptation is needed for forests to maintain their functioning status (adaptation for forests'). Forests are vulnerable to climate change and implementing forest adaptation measures can reduce the negative impacts (Locatelli, et.al, 2008). Second, forests play a role in adaptation of communities and the broader society (forests for people's adaptation'). Forest ecosystems contribute to adaptation by providing local ecosystem services that reduce societies 'vulnerability to climate change (Vignola, et.al, 2009).

As reported by (Tache and Irwin 2003); Some parts of Borana (Arero and Yabello) and nearby areas (e.g., Negele in the Guji zone) have forests of Juniperus procera.moreover there are NGO that works to promote community involvement in forest management in borena zone that is called SOS Sahel Ethiopia. For the communities close to these forests, the services provided by forests provide risk-mitigation opportunities and sustainable forest management may be developed as part of an adaptation strategy. For example, processed forest products may form livelihood diversification opportunities, or at least fall-back options for times of difficulty, particularly for women (Hurst et al., 2012).

\section{v. Resettlement Programs}

As stated in (FDRE,1995); The right to ownership of rural and urban land, as well as of all rural resources, is exclusively vested to the state and peoples of Ethiopia. On the other hand, Land in Ethiopia is owned by the national government, which often reallocates land for cropping and pasture as well as for resettlement (Hurst et al., 2012). Therefore, Ethiopian pastoralists have the right to free land for grazing and cultivation as well as the right not to be displaced from their own lands (FDRE,1995)

The reason given for the resettlements is that the haphazard settlement and growth of villages had resulted in conflict over grazing areas. Moreover, it is difficult to provide government services far away from the road. Therefore some villages have been relocated by the government closer to the main road, with designated satellite grazing areas for each village to reduce conflict. The effects of this resettlement on the rangeland and grazing practices, particularly traditional ones, are unclear. Better access to roads may help government and NGOs more easily provide services such as water, food aid, health, and extension, while also facilitating community access to markets, education, and alternative sources of employment (Hurst et al., 2012).

\section{Diversification of income source off-Pastoralism}

\section{i. Cropping}

The pastoral Borana in their past tradition frowned upon land tilling as an act of evil and disgrace (Berhanu, 2007). But, Recurrent drought was imposed an important foundation to pursue assets and incomes diversification as an opportunity to farming in responses to climate changes at the expenses of rangelands (Dirriba, 2016). As reported by In the last four decades, there has been a change among the Boran from almost no households involved in cultivation to a large majority of households involved in some form of cultivation, usually of maize and/or beans (Desta, 2011).

Farming is practically the post-drought option to insure their immediate family consumption. Beyond consumption focus, crop productions become an important business oriented practices. Especially, some elite practicing teff production, the cash crops in lowland, more intensively than other crops for market purposes (Dirriba, 2016) 


\section{ii. Investments into Petty Trade}

Many of the women and men mentioned that diversification into petty trade was a popular diversification strategy. Households can offset the fixed costs of traveling to market and take advantage of price differentials between the communities and market towns to generate income by selling community produced goods at market (e.g., forest and livestock products) or reselling manufactured or value-added products (e.g., grains and tea) back in the communities. Theoretically, there is the added advantage that increased petty trade may increase access to outside goods and stabilize prices in the communities (Hurst et al., 2012).

\section{iii. Off-Farm Employment (Local and Distant)}

Education is key for children because it provides them with the opportunity to find off-farm employment. Yet many of the boutique, hotel, and restaurant staff in the region were immigrants from other regions of the country, not Boran (Hurst et al., 2012). But when child become learnt they have to get those chance of off-farm employment and can be used as one mechanisms of adaptation to climate change.

\section{Water-Related adaptation and coping strategies}

Increased temperature and more critical drought conditions would likely erode the natural capital (resource) base of sustainable pastoralism which will be manifested though scarcity of pasture and water resources (Wassie and fekadu, 2015). Therefore, Water resources is a key resource affected during severe drought (Dirriba, 2016). The Borana have long been adapted to a landscape with little water. However with more frequent droughts, water availability has declined. Water management is therefore an important part of adapting to climate change. A number of strategies at various scales have been initiated by Boran communities as well as the government and NGOs to deal with the issue of water availability (Hurst et al., 2012).

\section{i. Traditional Water Systems}

Water points, in their natural existence, and be classified as pond (including crater), well (including borehole), and spring. Pastoralists make use of different water points in different time of year. In rain season, there is no need of water points because the water can be accumulated in any small ponds throughout the landscape. Within two to three months after rain season, pastoralists make use of the ponds. Pastoralists need to constantly maintain the ponds to ensure the water availability. During dry season, pastoralists need to use the wells (Chuan, 2014).

To cope with severe shortage of water during severe droughts, the pastoralists have been digging shallow and deep wells on the dry season along river bed and on the dry water pans (Dirriba, 2016). The Borana rangeland is composed of key grazing resources associated with the traditional deep water wells. (Galma, 2017). As documented by Hurst et al., (2012) Water management is deeply integrated into the Borana social structure. There are nine clusters of traditional deep wells, called tulas, around the region. Each well is administered by an abba ela, or "father of the well." Tula wells, whose exact origins are unknown, can often be tens of meters deep and are said to contain water even in very severe drought. These are therefore are an integral Boran strategy to mitigate the effects of drought. An abba hirega monitors the use of the well, which usually has a trough from which cattle are allowed to drink. Preference in usage is generally given to members of the clan to which the abba ela belongs. However, in general, any Boran may make a case to the community for permission to use the well. As reported by Helland (1980) These traditional water sources, particularly the tulas, are notable for having served the Boran for the duration of their existence in this region. They may therefore remain important in promoting sustainable water use while providing much needed water during times of drought. In addition to the deep wells, as denoted by Hurst et al., (2012) there are additionally many shallow wells, called Adadils, also exist, and function for shorter periods of time. Many of these wells are still in use, and several which are damaged are being "rehabilitated" by NGOs or the government.

\section{ii. Water Trucking and Storage Reservoir Construction}

As reported (Hurst et al., 2012); the government and NGOs send water trucks to villages Pparticularly in the time of emergencies. The quantity of water that can be sent in this way is limited due to infrastructure but also because of limited storage facilities in each village. Moreover, as water cannot be trucked very far, particularly under poor road conditions, the utility of this approach is limited if the entire region suffers drought. Water trucking is therefore at best an emergency measure for short durations. Better roads would facilitate the timely provision of water in periods of acute shortage.

In addtion to water trucking there are several large water projects present in the Borana, some of which go back several decades. For example, a water storage reservoir can be found near the Haro Bake livestock market. these may have been intended to provide water particularly in times of drought and many of them do serve this purpose, it appears that their utility has been hampered by these problems(Hurst et al., 2012).

\section{Conclussion}

Globally, climate change is one of the most environmental issues and challenges in the todays' world. It is also one of the major problem of the country of Etiopia in the same way and the country has long term climate related history. The Boran people which have been almost totally dependent for their livelihoods on the products of their cattle, using them as food or in trade for grain are one of the people who suffered by climatic change in the country 
of Ethiopia.Even though the degree and severity of the climate related problem is large in the area, peoples of the borena are known with having different types of adaptation and coping mechanisms with regard to climatic change. Those adaptation and coping mechanism which used adapted climatic change in borena peoples have different bases. They are; livestock-related, range-land related, income-diversification and water-related management adaptation and coping mechanisms.

From Live-stock related adaptation and copping mecanisms that used to climate changes in borena peple destocking is one the mechanism that used to reduce livestock size based on the severity of the problem. Livestock mobility is another survival and resource management strategy commonly practiced through traveling with their livestock in search of water and pasture. Likewise, Livestock diversification is another adaptation mechanisms relating to livestock which refers to raring of different variety of livestock to maintain animals that feed on different species of plants, increasing their options for extracting resources from the rangeland at the time of climatic change. In addtion to those measures traditional social insurance like busa gonafa, ames and rebaray served as adaptation measures.Similarly, maintaining animal health and improved management of livestock are ways of adapting climatic change.

The second, major adaptation and copping mechanism is range-land related that include traditional land classification based on grazing season, kallo enclosure reserve that set aside for lactating, sick or young animals,bush clearing is the mechanism that used to remove unwanted tree from the area, forest management that used to maintain the function of the forest and inturn that provide local ecosystem services that reduce societies "vulnerability to climate change, resettlement programs that used to for the reallocation of the land based on the availability of the resource.

Another major adaptation and coping mechanism that applied in borena people is diversification of income source outside of pastoralism through cropping, investments into petty trade and off-farm employment. The same to above mechanism water management is one of the major adaptation and copping mechanisms in borena pastoral people. This means as water is major intgaral resource of pastoral community the are some ways that used to manage water in borena people. In sense berena people have sophisticated traditional management system for water resource. In this case water is majorly managed through traditional institution through the classification of water based on seasons of the year and availability o the water. In addition to that today different water related project is constructed in the area to reduce vurnearability of the community at the time of climatic change. But, there are many diferrent challenges regarding to those adaptation and coping mechanism to that affect adaptive capacity of those measures. Those challenges have both natural and anthropogenic bases. Therefore the point listed out in recommendation part should be done to overcome these problems.

Based on the results of the this review the following points are recommended in order to sustain the adaptation and copping mechanisms of the Borana peoples' inturn to sustain their livelihood:

Biophysical and socioeconomic characterstics of pastoral community should be concerned before formulation and ratification of different law of the country.

* Attention should be paid to construct and maintain facilitity,service and infrastructure like road,health service and educational center work.

- Indegnous resources management knowledge of the people should be recognized as that of the modern system.

\& Different center that enhance indigenous knowledge of the community should be construct in different area of the country.

\& Government should undertake different educational travel between different community to share their experience to other areas, which will also have contribution to enhance ownership of the borena pastoral people.

* Monitoring and evalation of soil and water conservation measure and water harvesting technique should done based on the suitability and sustainablity of each measures.

* Awareness creation trainig should be given to diversification of income out side of livestock, and sustainability of those mechanism should be evaluated through scientific way of evalution the productivety of the identified mechanisms.

\# The existed knowledge regarding adatation and coping stratagies has to be scripted in the form of text book so that make a linkage between generations.

\section{Reference}

Ababa, A., 2007. Climate change national adaptation programme of action (Napa) of Ethiopia. National Meteorological Services Agency, Ministry of Water Resources, Federal Democratic Republic of Ethiopia, Addis Ababa.Liao, C., 2014. Case Study: Borana, Ethiopia.

Amamo, B.T.A.B.A. and Borko, T.T., 2017. Review on Climate Change Adaptation and Mitigation Mechanisms 
in Ethiopia. civilization, 9(12).

Angassa, A. and Baars, R.M., 2000. Ecological condition of encroached and non-encroached rangelands in Borana, Ethiopia. African Journal of Ecology, 38(4), pp.321-328.

Berhanu, W., Colman, D. and Fayissa, B., 2007. Diversification and livelihood sustainability in a semi-arid environment: A case study from southern Ethiopia. The Journal of Development Studies, 43(5), pp.871-889.

Cooper, P.J.M., Dimes, J., Rao, K.P.C., Shapiro, B., Shiferaw, B. and Twomlow, S., 2008. Coping better with current climatic variability in the rain-fed farming systems of sub-Saharan Africa: An essential first step in adapting to future climate change?. Agriculture, ecosystems \& environment, 126(1-2), pp.24-35.

CSA, 2008. Summary and statistical report of 2007 population and housing census: Population size by age and sex. Federal Democratic Republic of Ethiopia, Population Census Commission, Central Statistical Authority (CSA), December 2008.

Eriksen, S.H. and Marin, A., 2011. Pastoral pathways: climate change adaptation lessons from Ethiopia.

Federal Democratic Republic of Ethiopia, 1995. Constitution of the Federal Democratic Republic of Ethiopia. Federal Negarit Gazetta, 1(1).

Helland, J., 1994. Development interventions and pastoral dynamics in Southern Ethiopia: a discussion of natural resources management in Borana pastoralism. African studies Center, Boston University.

Hurst, M., Jensen, N., Pedersen, S., Shama, A. and Zambriski, J., 2012. Changing climate adaptation strategies of Boran pastoralists in southern Ethiopia.

Locatelli, B., Evans, V., Wardell, A., Andrade, A. and Vignola, R., 2011. Forests and climate change in Latin America: linking adaptation and mitigation. Forests, 2(1), pp.431-450.

Mard, 2008. National guidelines for livestock relief interventions in pastoralist areas of Ethiopia. Ministry of Agriculture and Rural Development, Federal Democratic Republic of Ethiopia.

Martin, A.N., Nike Inc, 2014. Shoe upper. U.S. Patent Application 29/465,796.

Martin, R., Müller, B., Linstädter, A. and Frank, K., 2014. How much climate change can pastoral livelihoods tolerate? Modelling rangeland use and evaluating risk. Global Environmental Change, 24, pp.183-192.

McCarthy, N., Kamara, A.B. and Kirk, M., 2003. Co-operation in Risky Environments: Evidence from Southern Ethiopia. Journal of African Economies, 12(2), pp.236-270.

Megersa, B., Markemann, A., Angassa, A., Ogutu, J.O., Piepho, H.P. and Zárate, A.V., 2014. Livestock diversification: an adaptive strategy to climate and rangeland ecosystem changes in southern Ethiopia. Human ecology, 42(4), pp.509-520.

Megersa, B., Markemann, A., Angassa, A., Ogutu, J.O., Piepho, H.P. and Zaráte, A.V., 2014. Impacts of climate change and variability on cattle production in southern Ethiopia: Perceptions and empirical evidence. Agricultural systems, 130 , pp.23-34.

Dirriba Mengistu (2016). Impacts of Drought and Conventional Coping Strategies of Borana Community, Southern Ethiopia Socio-economics Research Team, Yabello Pastoral and Dryland Agriculture Research Centre, Vol.6, Yabello, Ethiopia

Oba, G., 1998. Assessment of indigenous range management knowledge of the Booran pastoralists of Southern Ethiopia.

Oba, G., 2014. Climate change adaptation in Africa: an historical ecology. Routledge.

Omolo, N.A., 2010. Gender and climate change-induced conflict in pastoral communities: Case study of Turkana in northwestern Kenya. African Journal on Conflict Resolution, 10(2).

Schanbacher, B.D., 1984. Manipulation of endogenous and exogenous hormones for red meat production. Journal of Animal Science, 59(6), pp.1621-1630

Sector E., 2014. Determinants of agro-pastoralist climate change adaptation strategies: case of Rayitu Woredas, Oromiya Region, Ethiopia. Research Journal of Environmental Sciences, 8(6), pp.300-317.

Seideman, S.C., Cross, H.R., Oltjen, R.R. and Schanbacher, B.D., 1982. Utilization of the intact male for red meat production: a review. Journal of Animal Science, 55(4), pp.826-840.

Solomon, J., 2007. Living with X: A body mapping journey in the time of HIV and AIDS, facilitator's guide. Johannesburg: REPSSI.

Solomon, T.B., Snyman, H.A. and Smit, G.N., 2007. Cattle-rangeland management practices and perceptions of pastoralists towards rangeland degradation in the Borana zone of southern Ethiopia. Journal of environmental management, 82(4), pp.481-494.

Tache B (2010) Mapping with customary institutions in southern Ethiopia. Save the Children US and SOS Sahel Ethiopia, Addis Ababa, Ethiopia

Tache, B. and Irwin, B., 2003. Traditional institutions, multiple stakeholders and modern perspectives in common poverty: accompanying change within Borana pastoral systems.

Thornton, P.K., Jones, P.G., Owiyo, T.M., Kruska, R.L., Herrero, M. and Kristjanson, P., 2006. Mapping climate vulnerability and poverty in Africa. Report to the Department for International Development.

Tolera, A. and Abebe, A., 2007. Livestock production in pastoral and agro-pastoral production systems of southern 
Ethiopia. Livestock Research for Rural Development, 19(12), pp.4-7.

UNFCCC, F., 2007. Climate change: impacts, vulnerabilities and adaptation in developing countries. Bonn, Germany: United Nations Framework Convention on Climate Change.

Vignola, R., Locatelli, B., Martinez, C. and Imbach, P., 2009. Ecosystem-based adaptation to climate change: what role for policy-makers, society and scientists?. Mitigation and adaptation strategies for global change, 14(8), p.691.

Wako, H., Ishiuchi, S.I., Kato, D., Féraud, G., Dedonder-Lardeux, C., Jouvet, C. and Fujii, M., 2017. A conformational study of protonated noradrenaline by UV-UV and IR dip double resonance laser spectroscopy combined with an electrospray and a cold ion trap method. Physical Chemistry Chemical Physics, 19(17), pp.10777-10785.

Wassie B and Fekadu B (2015). Climate Variability and Household Adaptation Strategies in Southern Ethiopia; Sustainability 7, www.mdpi.com/journal/sustainability 6353-6375. 